\begin{tabular}{|c|l|}
\hline Title & Reconstruction of sea surface dimethy Isulfide in the North Pacific during 1970s to 2000s \\
\hline Author(s) & Watanabe, Y.W.; Y oshinari, H.; Sakamoto, A.; Nakano, Y.; Kasamatsu, N.; Midorikawa, T.; Ono, T. \\
\hline Citation & $\begin{array}{l}\text { Marine Chemistry, 103(3-4), 347-358 } \\
\text { https://doi.org/10.1016/.marchem.2006.10.004 }\end{array}$ \\
\hline Issue Date & 2007-01-16 \\
\hline Doc URL & http://hdl.handle.net/2115/20390 \\
\hline Type & article (author version) \\
\hline File Information & MC103-3-4.pdf \\
\hline
\end{tabular}

Instructions for use 


\section{Reconstruction of sea surface dimethylsulfide in the North Pacific during 1970s to $2000 \mathrm{~s}$}

Y. W. Watanabe ${ }^{1}$, H. Yoshinari ${ }^{2}$, A. Sakamoto ${ }^{1}$, Y. Nakano ${ }^{1,3}$, N. Kasamatsu ${ }^{4}$, T. Midorikawa ${ }^{5}$, and T. $\mathrm{Ono}^{3}$

1: Graduate School of Environmental Earth Science, Hokkaido Univ., Kita 10 Nishi 5, Sapporo, 060-0810, Japan

2: IPRC-SOEST, Univ. of Hawaii, 1680 East West Road, Honolulu, HI96822-2327, USA

3: Hokkaido National Fisheries Research Institute, Katsurakoi 116, Kushiro, 085-0802, Japan

4: National Institute of Polar Research, Kaga 1-9-10, Itabashi, Tokyo, 173-8515, Japan

5: Meteorological Research Institute, Nagamine 1-1, Tsukuba, 305-0052, Japan

Present affiliation:

H. Yoshinari: Japan Fisheries Information Service Center, Toyomi-cho 4-5, Tokyo, 104-0055, Japan.

Y. Nakano: Mutsu Institute for Oceanography, Japan Agency of Marine-Earth Science and Technology, Kitasekine 690, Mutsu, 035-0022, Japan.

Corresponding author:

Yutaka W. Watanabe

Graduate School of Environmental Earth Science, Hokkaido Univ., Kita 10 Nishi 5, Sapporo, 060-0810, Japan.

Tel: +81-11-706-2371; Fax: +81-11-706-2247; E-mail: yywata@ees.hokudai.ac.jp 


\begin{abstract}
We proposed an empirical equation of sea surface dimethylsulfide (DMS, nM) using sea surface temperature (SST, K), sea surface nitrate $(\mathrm{SSN}, \mu \mathrm{M})$ and latitude $\left(\mathrm{L},{ }^{\circ} \mathrm{N}\right)$ to reconstruct the sea surface flux of DMS over the North Pacific between $25^{\circ} \mathrm{N}$ and $55^{\circ} \mathrm{N}: \ln D M S=0.06346 \cdot S S T-0.1210 \cdot$ $S S N-14.11 \cdot \cos (L)-6.278\left(R^{2}=0.63, p<0.0001\right)$. Applying our algorithm to climatological hydrographic data in the North Pacific, we reconstructed the climatological distributions of DMS and its flux between $25^{\circ} \mathrm{N}$ and $55^{\circ} \mathrm{N}$. DMS generally increased eastward and northward, and DMS in the northeastern region became to 2 - 5 times as large as that in the southwestern region. DMS in the later half of the year was 2 - 4 times as large as that in the first half of the year. Moreover, applying our algorithm to hydrographic time series datasets in the western North Pacific from 1971 to 2000, we found that DMS in the last three decades has shown linear increasing trends of $0.03 \pm 0.01 \mathrm{nM} \mathrm{y}^{-1}$ in the subpolar region, and $0.01 \pm 0.001 \mathrm{nM} \mathrm{yr}^{-1}$ in the subtropical region, indicating that the annual flux of DMS from sea to air has increased by $1.9-4.8 \mu \mathrm{mol} \mathrm{m}^{-2} \mathrm{yr}^{-1}$. The linear increase was consistent with the annual rate of increase of $1 \%$ of the climatological averaged flux in the western North Pacific in the last three decades.
\end{abstract}

Keywords: Dimethylsulfide; Algorithm; Decadal change; North Pacific 


\section{Introduction}

DMS is produced by marine phytoplankton activity, and its content in the surface mixed layer is supersaturated with respect to the atmosphere. Consequently, the net flux of DMS is driven from sea to air. In the atmosphere, DMS is rapidly oxidized to form sulfur aerosols, and the cloud condensation nuclei derived from DMS acts to counter global greenhouse warming. Thus it is important to understand the spatiotemporal distribution of DMS flux for predicting future global climate change (e.g., Andreae, 1990). To understand the global oceanic distribution of DMS, several attempts have been tried to parameterize the global spatiotemporal distribution of sea surface DMS using oceanic climatological parameters (chlorophyll-a $(\mathrm{Chl})$, light intensity $(\mathrm{I})$, nutrients $(\mathrm{N})$, surface mixed layer depth (MLD)) or using ocean models (Anderson et al., 2001; Simó and Dachs, 2002; Aumont et al., 2002; Chu et al., 2003; Belviso et al., 2004a). However, Belviso et al. (2004b) demonstrated that there were large uncertainties and spatial differences of sea surface DMS between these studies. Especially, in the North Pacific, even the algorithm of Simó and Dachs (2002) showing the results of being the most similar to the observational sea surface DMS, gave the values under half of the observational data.

On the other hand, recent studies of global climate change have reported the possibility that recent oceanic conditions have changed due to the effect of anthropogenically induced greenhouse warming and/or natural climate change (e.g., Levitus et al., 2000; Hansen et al., 2002). In the North Pacific, some studies have already showed the changes of chemical components with the decrease of sea surface water density, suggesting the weakening of the surface-deep water mixing derived from artificial greenhouse warming effects and/or natural climate change (Ono et al., 2001; Watanabe et al., 2001; Watanabe et al., 2003; Emerson et al., 2004). Consequently, the abundances of phytoplankton and $\mathrm{Chl}$ in the surface mixed layer have been shown to decrease in the North Pacific subpolar and subtropical regions (e.g., Gregg and Conkright, 2002; Chiba et al., 2004; Watanabe et al., 2005). In addition, Karl et al. (2001) indicated the increase of nitrogen fixing smaller-size phytoplankton in the subtropical region, and Ishida et al. (2006) demonstrated a possible of a shift in the phytoplankton 
from larger size of $>3 \mu \mathrm{m}$ to smaller size of $<3 \mu \mathrm{m}$, suggesting the possibility a domain shift of phytoplankton from large size species to small size species as a high-producer group of DMS (e.g., Malin and Kirst, 1997). According to these biogeophysical decadal changes in the North Pacific, it is important to clarify whether the flux of oceanic DMS has changed or not. In the North Pacific, therefore, we tried to construct a spatiotemporal algorithm of sea surface DMS based on the observational sea surface DMS with other hydrographic multiple parameters in the North Pacific, and to reconstruct the long-term change of sea surface DMS in the North Pacific subpolar and subtropical regions during the last several decades.

\section{Data and Method}

\subsection{Concept for construction of DMS algorithm}

As the concentration of sea surface DMS relates to the phytoplankton activity (e.g., Malin and Kirst, 1997), we here assumed the concentration of DMS as the biological parameters relating to a growth rate of phytoplankton. It can be generally expressed by the following exponential function:

$D M S=a \cdot B_{o} \cdot \exp \left(f_{(S S T, I, N)}\right)$

where ' $a$ ', ' $B_{o}$ ', 'SST', ' $I$ ' and ' $N$ ' are the coefficient of transformation from $B_{0}$ to $D M S$, the initial phytoplankton biomass, the sea surface temperature, the light intensity, and the concentration of nutrient, respectively. Until now, it was difficult to measure both $B_{o}$ and $I$ with DMS in the observational time simultaneously. In many hydrographic observations, Chlorophyll-a (Chl) has generally been measured as an index of biological activity. It is possible that an averaged meridional pattern of $I$ is roughly similar to that of the cosine of latitude due to derivation of sun radiation. Most of phytoplankton activities are generally limited by nitrate or iron in the surface mixed layer (e.g., Imai et al., 2002). We therefore tried to use Chl, the cosine of latitude at the observational position $(\cos (\mathrm{L}))$ and the sea surface nitrate $(\mathrm{SSN})$, as proxies of $B_{o}, I$ and $N$, respectively: 
where ' $b$ ' is the coefficient of transformation from $B_{0}$ to $C h l$.

It is actually difficult to know $f_{(S S T, \cos (L), S S N)}$ directly. In such case, the multiple linear regression technique has been generally useful to clarify the relationship between several parameters in many hydrographic researches (e.g., Sabine et al., 2004). Assuming that $f_{(S S T, \cos (L), S S N)}$ can be expressed by multiple linear regression, therefore, we can obtain the following equation:

$D M S=a \cdot b \cdot C h l \cdot \exp (c \cdot S S T+d \cdot \cos (L)+e \cdot S S N+f)$

where ' $c-f$ ' are constants. ' $f$ ' is the intercept in the multiple linear regression. Expressing Eqn. (3) as natural logarithm form, we can obtain the following equation:

$$
\begin{aligned}
\ln D M S & =\ln a+\ln b+\ln C h l+c \cdot S S T+d \cdot \cos (L)+e \cdot S S N+f \\
& =\ln C h l+c \cdot S S T+d \cdot \cos (L)+e \cdot S S N+g
\end{aligned}
$$

where ' $g$ ' is the sum of $\ln a, \ln b$ and $f$. Substituting all the observational DMS data equipped with Chl, SST and SSN for Eqn. (4) over the North Pacific, we tried to carry out a statistical test in order to validate the usefulness of each parameter in the multiple linear regression.

\subsection{Data}

To construct an algorithm of sea surface DMS (nM) over the North Pacific based on Eqn. (4), we used all the observational DMS data set equipped with Chl $(\mu \mathrm{g} / \mathrm{l})$, SST $(\mathrm{K})$ and $\mathrm{SSN}(\mu \mathrm{M})$ from the 1980 s to the 2000s over the northern North Pacific (Watanabe et al., 1995a; Watanabe et al., 1995b; Aranami et al., 2002; Wong et al., 2005; Institute of Ocean Sciences, 2006; our new data) (the 
component in each decade: 1980s (14\%), 1990s (67\%), 2000s (19\%)) (Fig. 1 and Table 1). All the data set we addressed were 504 data set collected in $0 \mathrm{~m}-20 \mathrm{~m}$ depths in the region from $25^{\circ} \mathrm{N}$ to 55 ${ }^{\circ} \mathrm{N}$, including all seasons (the component in each period: January-March (18\%), April-June (43\%), July-September (36\%), October-December (3\%)). DMS was usually measured by the general pre-concentrated gas-chromatographic method (e.g., Watanabe et al., 1995a). We also used the datasets of Chl and SSN measured by the solvent extraction photoflurometrical method (Yentsch and Menzel, 1963), and the copper-cadmium sulfanilamide reduction method (Strickland and Parsons, 1968). The precisions of DMS, SSN and Chl were estimated to be approximately $\pm 6 \%, \pm 2 \%$ and \pm $10 \%$, respectively, which were obtained from duplicate determinations in the surface water.

\section{Results and Discussion}

\subsection{Parameterization of sea surface DMS over the North Pacific}

In general, the F-test is used to validate the usefulness of each parameter in the multiple linear regression. In this our study, the parameter with $\mathrm{F}$ value of more than 2.4 has a significant meaning (e.g., Wilks, 1995), indicating that it is useful to obtain an empirical equation in the multiple linear regression. By using a stepwise linear fitting regression for Eqn. (4) with F-test, the first term of right-hand side in Eqn. (4), ln $C h l$ was only found to become negligible $(F=1.9)$ due to $F<2.4$ and it can therefore be deleted. We obtained the algorithm for sea surface DMS as follows (Fig. 2a).

$$
\begin{aligned}
& \ln (D M S)=0.06346 \cdot S S T-0.1210 \cdot S S N-14.11 \cdot \cos (L)-6.278 \\
& \left(R^{2}=0.63, p<0.0001, R M S E=0.65, n=504 ; F=12 \text { for } S S T, F=35 \text { for } S S N, F=630\right. \text { for } \\
& \cos (L))
\end{aligned}
$$

where ' $R$ ', ' $p$ ', 'RMSE' and ' $n$ ' are the coefficient of determination, the probability at a $95 \%$ confidence level, the root mean standard error of regression and the number of samples, respectively. 
This algorithm can explain $63 \%$ of the variance of sea surface DMS with RMSE of 1.9 nM over the North Pacific in the last three decades, without using Chl. The sensitivity of our algorithm to each parameter between $25^{\circ} \mathrm{N}$ and $55^{\circ} \mathrm{N}$ was $0.1 \mathrm{nM} /{ }^{\circ} \mathrm{C}, 0.2 \mathrm{nM} / \mu \mathrm{M}-\mathrm{SSN}$ and $0.3 \mathrm{nM} /$ degree-L, which was derived from the coefficient of each parameter in Eqn. (5). Our algorithm of DMS largely depends on cos (L) as a function of latitude. Kettle et al. (1999) showed that sea surface DMS had good correlation with latitudinal position from $25{ }^{\circ} \mathrm{N}$ to $70{ }^{\circ} \mathrm{N}$ although there are no similar correlations on a global scale. Some studies also reported no correlation between sea surface DMS and Chl (e.g., Watanabe et al., 1995a). Thus the selection of parameters in our algorithm could be adequate to reconstruct the sea surface DMS in the North Pacific.

We here tried to compare our DMS algorithm with the previous study's algorithm that showed the results of being the most similar to the observational DMS (Simó and Dachs, 2002). The algorithm of Simó and Dachs (2002) was based on the ratio of Chl and the surface mixed layer depth with a difference of $0.125 \sigma_{\theta}$ from the surface density (MLD, m). Thus we here used the same data set of Chl as used to construct our DMS algorithm (see Subsection 2.2). In these observational data positions, we calculated the monthly MLD based on climatological monthly data of temperature and salinity from World Ocean Atlas 2001 (WOA 2001) (Stephens et al., 2002; Boyer et al., 2002). Applying the above Chl and MLD into their algorithm, we compared the results of sea surface DMS between theirs and our algorithm. Their algorithm led to significant scatter $\left(R^{2}=0.19, R M S E=0.96\right.$, $n=504$ ) (Fig. 2b), suggesting that our algorithm is more advantageous way than the previous other ones due to $R^{2}=0.63$ for our algorithm, in order to reconstruct the spatiotemporal distribution of sea surface DMS over the North Pacific.

Furthermore, evaluating the usefulness of our algorithm of sea surface DMS in the North Pacific, we tried to apply our algorithm to the independent observational data of sea surface DMS, the eastern Pacific (EP) line data along $140^{\circ} \mathrm{W}$ from $25^{\circ} \mathrm{N}$ to $55^{\circ} \mathrm{N}$ (April-May in $1993, \mathrm{n}=163$ ) (Bates and Quinn, 1997) which were not used to obtain Eqn. (5), because this region was covered by the construction of our algorithm (Fig. 1 and Table 1). We here used an empirical equation of SSN 
derived from SST and Chl (Goes et al., 2000) in order to apply SSN to Eqn. (5) because the EP line had no data of SSN despite being of the dataset of SST and Chl. In both observed and predicted DMS, we found that an averaged concentration of sea surface DMS increased northward in EP line (Fig. 2a), which were consistent with the general previous work (Kettle et al., 1999). The predicted DMS agreed with these independent observational data of sea surface DMS within the uncertainty of our approach that discussed in the above section, suggesting that our algorithm of sea surface DMS is useful over the North Pacific at least in the region from $25^{\circ} \mathrm{N}$ to $55^{\circ} \mathrm{N}$.

\subsection{Reconstruction of climatological monthly sea surface DMS in the North Pacific using WOA 2001}

To understand the climatological distributions of sea surface DMS and its flux is an essential step for clarifying the long-term changes of DMS in the North Pacific. Thus we estimated the monthly mean concentration of sea surface DMS in the North Pacific by using climatological monthly mean dataset of SST and SSN from WOA 2001 (Stephens et al., 2002; Conkright et al., 2002) with our DMS algorithm (Fig. 3). In the North Pacific, the concentration of sea surface DMS generally increased eastward and northward. DMS in the northeastern region become to 2 - 5 times as large as that in the southwestern region, which agreed with the previous observational works (e.g., Kettle et al., 1999). In addition, we found that the concentration of sea surface DMS in the later half of the year (July - December) was 2 - 4 times as large as that in the first half of the year (January - June). In this period, DMS in the northeastern region remarkably increases by more than $10 \mathrm{nM}$ while DMS almost did not change in the southwestern region, which agreed with the previous observational results (Wong et al., 2005; Kettle et al., 1999). We estimated that the annual mean concentration of sea surface DMS was $2.2 \mathrm{nM}$ between $25^{\circ} \mathrm{N}$ and $55^{\circ} \mathrm{N}$ in the North Pacific, which was equal to that in the previous observational work (Kettle et al., 1999). In general, larger size phytoplanktons such as diatoms are dominant to other species in the North Pacific. The concentration of silicate in the North Pacific surface mixed layer decreases eastward (Conkright et al., 2002), and consequently the 
abundance of phytoplanktons with calcification such as coccolithophorids increases eastward (e.g., Honda, 2003). Compared to the western North Pacific, in the eastern North Pacific region where low diatom production and high calcification occurs (e.g., Wong et al., 2002), the increase of phytoplanktons with calcification such as coccolithophorids, seemed to bring the higher concentration of sea surface DMS. In the first half of the year, diatoms bloom and their biomass decreases with the depletion of silica and/or iron. In the second half of the year, smaller size phytoplanktons such as coccolithophorids become dominant instead of diatoms (e.g., Honda et al., 2002). The difference of phytoplankton species as a producer group of DMS (e.g., Malin and Kirst, 1997) between the eastern and western regions may mainly cause the spatiotemporal distribution of DMS in the North Pacific.

According to Fig. 3, multiplying the monthly $\mathrm{DMS}_{\mathrm{p}}$ with the climatological monthly wind data at $10 \mathrm{~m}$ height calculated from the NCEP/NCAR reanalysis data (NCEP/NCAR Reanalysis Project, 2006), the gas transfer velocity according to Wanninkhof and McGillis (1999), and the Schmidt number calculated according to Saltzman et al. (1993), and integrating the above estimation between $25^{\circ} \mathrm{N}$ and $55^{\circ} \mathrm{N}$ in the North Pacific, we here calculated the annual total flux of DMS from sea to air ( $\left.\mathrm{F}_{\mathrm{DMS}}\right)$ over this region. In this region, we estimated the climatological seasonal $\mathrm{F}_{\mathrm{DMS}}$ to be $0.08 \mathrm{Tg}-\mathrm{S}$

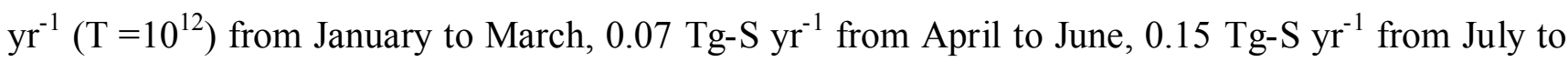
September, and $0.17 \mathrm{Tg}_{-} \mathrm{S} \mathrm{yr}^{-1}$ from October to December, indicating that $\mathrm{F}_{\mathrm{DMS}}$ in the later half of the year (July - December) is about $70 \%$ of total annual flux of DMS over this region $\left(0.47 \mathrm{Tg}^{-\mathrm{S} \mathrm{yr}^{-1}}\right)$. In this region that corresponds to $8 \%$ of global ocean's area, the climatological annual total flux of DMS from sea to air was found to be $1-3 \%$ of global flux of DMS predicted in the previous works (e.g., Bates et al., 1992; Watts, 2000), which is smaller than the global mean flux of DMS per area. The main reason may be due to exiguousness of small size species as a high-producer group of DMS (e.g., Malin and Kirst, 1997) compared to the North Atlantic Ocean despite this region being one of the largest primary productivity derived from the diatom species (e.g., Honda et al., 2002).

\subsection{Decadal changes of sea surface DMS}


To understand the possibility of decadal change of DMS in the ocean is an important step for clarifying the impact of DMS flux from sea to air on global warming. However, it may be difficult for the present DMS algorithms to estimate the decadal change of DMS. In even our algorithm of DMS, there was a large error of $1.9 \mathrm{nM}$. If we here try to apply our algorithm to an arbitrary fixed ocean observational point, the third term of right-hand side $(\cos (L))$ in Eqn. (5) of our algorithm can be addressed as a constant for time although both SST and SSN have temporal changes. The relative error of $\cos (L)$ becomes zero. Consequently, if we focus on the relative temporal change of sea surface DMS in arbitrary fixed observational point, RMSE can decrease by $0.7 \mathrm{nM}$ in our algorithm, which is about one third relative to original RMSE in our algorithm. Thus it may allow us to estimate the decadal change of sea surface DMS in the arbitrary fixed observational point by using our algorithm of DMS.

We here applied our algorithm to the time series data of hydrographic parameters including SST and SSN in the subpolar (SP) and subtropical (ST) regions in the western North Pacific from 1971 to 2000 that was conducted by Japan Meteorological Agency (2001) (Fig. 1 and Table 1), which is also available from the Japan Oceanographic Data Center [http://www.jodc.go.jp/service.htm]. In SP region, the R/V Kofu-Maru has conducted the hydrographic observations 4 - 5 times a year at one degree interval along $42{ }^{\circ} \mathrm{N}$ in the Oyashio region. In general, in the western North Pacific subpolar region, we can find the largest phytoplankton bloom from April to June and the strongest stratification of the surface mixed layer from July to September (e.g., Tsurushima et al., 2002). Thus we divided the time series data into four seasonal periods (January - March (J-M), April - June (A-J), July-September (J-S), October - December (O-D)). On the other hand, in ST region, the R/V Ryofu-Maru has observed the hydrographic data at one degree interval from $25^{\circ} \mathrm{N}$ to $34^{\circ} \mathrm{N}$ along $137^{\circ} \mathrm{E}$ in the winter (January-February (J-M)) and the summer (August - September (J-S)). We addressed an averaged seasonal value of each parameter (SST and SSN) in the two regions, which was expressed as three-year running mean composites with standard errors $(\mathrm{SE}, \pm 1 \sigma)$ for neglecting large anomaly of DMS derived from anomalies of observed SST and SSN. 
We here demonstrated the temporal change of sea surface DMS $\left(\mathrm{DMS}_{\mathrm{p}}\right)$ reconstructed in each season in the western North Pacific by using Eqn. (5) (Figs. 4a and 4b). To confirm the temporal usefulness of our algorithm, we also plot the independent observational data of sea surface DMS $\left(\mathrm{DMS}_{\mathrm{o}}\right)$ (2004 in SP region; 1991 in ST region) in each season (Figs. 4a and 4b, Table 1), which were not used to obtain Eqn. (5). In SP region, an averaged difference between $\mathrm{DMS}_{\mathrm{p}}$ and $\mathrm{DMS}_{\mathrm{o}}$ was $0.3 \pm$ $0.01 \mathrm{nM}$, and $\mathrm{DMS}_{\mathrm{p}}$ in all seasons were consistent with $\mathrm{DMS}_{\mathrm{o}}$ within RMSE of $0.7 \mathrm{nM}$. On the other hand, in ST region, we found that $\mathrm{DMS}_{\mathrm{p}}$ agreed with $\mathrm{DMS}_{\mathrm{o}}$ within the difference of $0.2 \pm 0.1 \mathrm{nM}$, which was also consistent with $\mathrm{DMS}_{\mathrm{o}}$ within RMSE of $0.7 \mathrm{nM}$ although $\mathrm{DMS}_{\mathrm{p}}$ in wintertime was slightly higher than $\mathrm{DMS}_{\mathrm{o}}$ due to probably the insufficient of wintertime data for constructing our algorithm and due to the low SSN values close to detection limit. Considering the above results, it is possible that our algorithm could be useful for reconstructing the decadal change of sea surface DMS in the western North Pacific.

We tried to clarify the decadal changes of DMS in the western North Pacific. In both SP and ST regions, we found that the climatological averaged value of $\mathrm{DMS}_{\mathrm{p}}$ from July to December was significantly higher (average: SP region $=2.8 \pm 0.1 \mathrm{nM}$; ST region $=1.5 \pm 0.02 \mathrm{nM}$ ) than that from January to June (average: SP region $=0.7 \pm 0.1 \mathrm{nM}$; ST region $=0.9 \pm 0.01 \mathrm{nM}$ ). In general, diatoms are dominant to other species in the North Pacific. In the first half of the year, they bloom and their biomass decreases with the depletion of silica and/or iron. In the second half of the year, smaller size phytoplanktons such as coccolithophorids become dominant instead of diatoms (e.g., Honda et al., 2002). In addition, from the first to the second halves of the year, Imai et al. (2002) found the remarkable decrease of larger size phytoplankton ( $>10 \mu \mathrm{m}$ fraction) from $34 \%$ to $8 \%$ in the western North Pacific. The differences of sea surface DMS between the first and second halves of the year, may be influenced by the seasonal change of different phytoplankton species.

Moreover, we here focused on the long-term trend of sea surface DMS. By using the simple linear regression, $\mathrm{DMS}_{\mathrm{p}}$ has significantly shown an averaged linear increase of $0.03 \pm 0.01 \mathrm{nM} \mathrm{yr}^{-1}$ in SP region $(p<0.01)$, and $0.01 \pm 0.001 \mathrm{nM} \mathrm{yr}^{-1}$ in ST region $(p<0.01)$, indicating that the sea surface 
DMS has increased by $0.9 \mathrm{nM}$ in SP region, and by $0.3 \mathrm{nM}$ in ST region during the past three decades. Even if considering RSME of $0.7 \mathrm{nM}$ in our algorithm, DMS in SP region significantly had shown the linear increasing trend at least in the last three decades while that in ST region may increase although it was not significant. In the two regions, some studies reported that water temperature has increased by $0.2-1.5^{\circ} \mathrm{C} \mathrm{yr}^{-1}$ and the concentration of nitrate has decreased by $0.3-1.5 \mu \mathrm{M} \mathrm{yr}^{-1}$ in the past three decades (Watanabe et al., 2003; Chiba et al., 2004; Watanabe et al., 2005). Because the sensitivity of DMS in our algorithm between $25^{\circ} \mathrm{N}$ and $55^{\circ} \mathrm{N}$ has $0.1 \mathrm{nM} /{ }^{\circ} \mathrm{C}$ and $0.2 \mathrm{nM} / \mu \mathrm{M}-\mathrm{SSN}$ respectively, these parameters' changes can explain $75 \%$ of an averaged increase of DMS in the two regions in the past three decades in the case of maximum decadal changes of water temperature and nitrate. It suggested that our algorithm is almost useful to construct the spatiotemporal distribution of sea surface DMS at least in the western North Pacific.

In order to clarify the extent of decadal periodicity of DMS with the long-term linear trend, according to previous studies (Ono et al, 2001; Watanabe et al., 2003; Watanabe et al., 2005), we assumed that the long-term change of sea surface DMS can be expressed by the Fourier sine expansion as follows:

$D M S=h \cdot y+i+j \cdot \sin \{2 \pi(y-k) / l\}$

where ' $y$ ' is the calendar year, ' $h$ '- ' $l$ ' are constants. Applying this equation to time series of $\mathrm{DMS}_{\mathrm{p}}$ in Fig. 4 , we found the averaged periodicity of $11.9 \pm 0.5$ years in the two regions $(R=0.70 \pm 0.05, p<$ 0.05), superimposed on the above linear increasing trend. Although the periodicity of DMS has slightly been shorter than those of $\mathrm{O}_{2}, \mathrm{PO}_{4}$ and $\mathrm{Chl}$ over the North Pacific (oscillation of about 18 year) (Ono et al., 2001; Watanabe et al., 2003; Watanabe et al., 2005), the increasing trend of DMS seemed to be opposite to the temporal decreasing trends in diatom and zooplankton biomass (Chiba et al., 2004). The decreases of diatom and zooplankton biomass may affect the increase of sea surface DMS due to the increase of smaller size phytoplankton as a high producer group of DMS and the 
decline of grazing effect of zooplankton, although it is actually difficult to clearly explain the cause of decadal periodicity of DMS due to the complicated changes of hydrographic biogeophysical parameters.

Recent reports showed that $\mathrm{Chl}$ has declined in the past three decades in both the subpolar and subtropical regions in the western North Pacific due to the weakening of the surface-deep water mixing (Watanabe et al., 2001; Gregg and Conkright, 2002; Chiba et al., 2004; Watanabe et al., 2005), indicating the decrease of larger size phytoplankton as diatoms (Chiba et al., 2004). The weakening of the surface-deep water mixing was caused by both the increasing temperature and the decreasing salinity in the two regions (Ono et al., 2001; Andreev and Watanabe, 2002; Watanabe et al., 2003; Watanabe et al., 2005). Consequently, MLD has shoaled although the long-term trend of MLD has been not significant due to large variation, and the nutrients in the surface mixed layer have decreased (Watanabe et al., 2005). In addition, some studies have already reported that the blooms of phytoplankton producing DMS tend to be restricted in shallower mixed layer (e.g., Malin and Kirst, 1997). Karl et al. (2001) and Ishida et al. (2006) also showed the possibility of a domain shift of phytoplankton from lager size to smaller size in the North Pacific in the past several decades. In the high latitude of North Pacific, smaller size phytoplanktons such as coccolithophorids may tend to be dominant with the decline of grazing effect of zooplankton instead of diatoms (e.g., Chiba et al., 2004). Thus the linear increasing trend of sea surface DMS with the decadal periodicity may be caused by the above domain shift of phytoplankton derived from the weakening of the surface-deep water mixing in the North Pacific.

Moreover, we estimated the decadal change in flux of DMS from sea to air $\left(\mathrm{F}_{\mathrm{DMS}}\right)$ in SP and ST regions, by multiplying $\mathrm{DMS}_{\mathrm{p}}$ with the seasonal wind data at $10 \mathrm{~m}$ height from the NCEP/NCAR reanalysis data (NCEP/NCAR Reanalysis Project, 2006), the gas transfer velocity according to Wanninkhof and McGillis (1999), the Schmidt number calculated according to Saltzman et al. (1993) and Eqn. (5) (Figs. 4c and 4d). We found that the annual averaged $\mathrm{F}_{\mathrm{DMS}}$ was $248 \pm 10 \mu \mathrm{mol} \mathrm{m}^{-2} \mathrm{yr}^{-1}$ in ST region, and $336 \pm 53 \mu \mathrm{mol} \mathrm{m}^{-2} \mathrm{yr}^{-1}$ in SP region. In the later half of the year, we found higher 
averaged $\mathrm{F}_{\mathrm{DMS}}$ over $250 \mu \mathrm{mol} \mathrm{m} \mathrm{yr}^{-1}$ in both regions $\left(\mathrm{J}-\mathrm{S}\right.$ in ST region $=280 \pm 10 \mu \mathrm{mol} \mathrm{m}^{-2} \mathrm{yr}^{-1} ; \mathrm{J}-\mathrm{S}$ in $\mathrm{SP}$ region $=303 \pm 30 \mu \mathrm{mol} \mathrm{m} \mathrm{yr}^{-1}$; O-D in SP region $=872 \pm 81 \mu \mathrm{mol} \mathrm{m} \mathrm{yr}^{-1}$ ), which were derived from the high content of DMS, the low Schmidt number and/or the strong wind speed. In the

second half of the year in the past thirty years, the linear trend of $F_{D M S}$ has increased by $2.8 \mu$ mole $\mathrm{m}^{-2}$ $\mathrm{yr}^{-1}$ in ST region $(p<0.01)$, and by $18.8 \mu$ mole $\mathrm{m}^{-2} \mathrm{yr}^{-1}$ in SP region $(p<0.01)$, which was equal to the seasonal rate of increase of $1-2 \%$ of the climatological seasonal averaged $\mathrm{F}_{\mathrm{DMS}}$ in the two region. Converting the above seasonal linear increasing trends of $\mathrm{F}_{\mathrm{DMS}}$ into annual averages, we estimated a linear increase of $1.9-4.8 \mu$ mole $\mathrm{m}^{-2} \mathrm{yr}^{-1}$, which was equal to the annual rate of increase of about $1 \%$ of the climatological annual averaged $F_{D M S}$ in the two regions in the last three decades in the western North Pacific.

\section{Concluding remarks}

We established an empirical equation of sea surface DMS (nM) using sea surface temperature $(\mathrm{SST}, \mathrm{K})$, sea surface nitrate $(\mathrm{SSN}, \mu \mathrm{M})$ and latitude $\left(\mathrm{L},{ }^{\circ} \mathrm{N}\right)$ to reconstruct the sea surface flux of DMS over the North Pacific between $25^{\circ} \mathrm{N}$ and $55^{\circ} \mathrm{N}: \ln D M S=0.06346 \cdot S S T-0.1210 \cdot S S N-$ $14.11 \cdot \cos (L)-6.278\left(R^{2}=0.63, p<0.0001\right)$.

Applying our algorithm to climatological hydrographic datasets in the North Pacific, we reconstructed the climatological monthly distribution of DMS. We found that the concentration of sea surface DMS generally increased eastward and northward, and DMS in the northeastern region became to 2 - 5 times as large as that in the southwestern region. The concentration of DMS in the later half of the year (July - December) was 2 - 4 times as large as that in the first half of the year (January - June).

Furthermore, applying our algorithm to hydrographic time series datasets in the western North Pacific from 1971 to 2000, we demonstrated that sea surface DMS in the last three decades has shown the linear increasing trends of $0.03 \pm 0.01 \mathrm{nM} \mathrm{y}^{-1}$ in the subpolar region, and $0.01 \pm 0.001 \mathrm{nM} \mathrm{yr}^{-1}$ in the subtropical region, indicating that the annual flux of DMS from sea to air has increased by 1.9 - 
$4.8 \mu \mathrm{mol} \mathrm{m} \mathrm{yr}^{-1}$ in the western North Pacific. The increase was equal to the annual rate of increase of about $1 \%$ of the climatological annual averaged $F_{D M S}$ in the western North Pacific in the last three decades

Satellite measurements have recently reproduced detailed spatiotemporal distribution of SST, Chl and the wind speed. On the other hand, Goes et al. (2000) has already reported an algorithm of SSN derived from SST and Chl with high precision. Using satellite data with their SSN algorithm, our algorithm will allow us to estimate the detailed spatiotemporal distributions of sea surface DMS and its flux over the North Pacific, and to detect the detailed seasonal change and decadal trend of DMS in the future.

However, it may be difficult to apply our present algorithm to the future prediction of DMS due to insufficient observational time-series of DMS with other hydrographic parameters. It would be necessary to improve the algorithm of DMS based on the many observational data. To improve the algorithm, it is an essential step to collect DMS data equipped with multiple hydrographic parameters such as chlorophyll-a, water temperature and nutrients in the data centers having many hydrographic observational data (e.g., Global Surface Seawater Dimethylsulfide Database, 2006). Unfortunately, there were actually few datasets of multiple hydrographic parameters with DMS data in the data centers. In the future, it will be necessary to continue obtaining accurate and long time series data of DMS with other hydrographic parameters and collecting them over the North Pacific to predict the effect of DMS on global warming.

\section{Acknowledgments}

We would like to express our gratitude to the many scientists and technicians who measured the hydrographic data along $137^{\circ} \mathrm{E}$ and $42{ }^{\circ} \mathrm{N}$ for their dedicated work of long-term observation. Our special thanks are given to Mr. Y. Fujii for his great effort to collect water samples. We also extend our profound thanks to two anonymous reviewers for their many fruitful comments. We used the wind data and the climatological data as follows and would like to express our gratitude to them: the 
NCEP/NCAR Reanalysis data provided by the NOAA-CIRES Climate Diagnostics Center, from their Web site at http://www.cdc.noaa.gov/cdc/reanalysis/, and the complied data from 'World Ocean Atlas 2001' by the data management group of the Graduate School of Environmental Science of Hokkaido University. We also appreciate the support of JAMSTEC, NOAA and NASA in this study (IPRC/SOEST contribution number: XXX/YYY). 


\section{References}

Anderson, T. R., Spall, S. A., Yool, A., Cipollini, P., Challenor, P. G., Fasham, M. J. R., 2001. Global field of sea surface dimethylsulfide predicted from chlorophyll, nutrients and light. J. Mar. Syst. 30, 1-20.

Andreae, M. O., 1990. Ocean-atmosphere interactions in the global biogeochemical sulfur cycle. Mar. Chem. 30, 1-29.

Andreev, A. G., Watanabe, S., 2002. Temporal changes in dissolved oxygen of the intermediate water in the subarctic North Pacific. Geophys. Res. Lett., 29(14), doi:10.1029/2002GL015021.

Aranami, K., Watanabe, S., Tsunogai, S., Ohki, A., Miura, K., Kojima, H., 2002. Chemical assessment of oceanic and terrestrial sulfur in the marine boundary layer over the northern North Pacific during summer. J. Atm. Chem. 41, 49-66, doi:10.1023/A:103896011709.

Aumont, O., Belviso, S., Monfray, P., 2002. Dimethylsulfoniopropionate (DMSP) and dimethylsulfide (DMS) sea surface distributions simulated from a global three-dimensional ocean carbon cycle model. J. Geophys. Res. 107(C4), doi:10.1029/1999JC000111.

Bates, T. S., Lamb, B. K., Guenther, A., Dignon, J., Stoiber, R. E., 1992. Sulfur emissions to the atmosphere from natural sources. J. Atm. Chem. 14, 315-337, doi:10.1007/BF00115242.

Bates, T. S., Quinn, P. K., 1997. Dimethylsulfide (DMS) in the equatorial Pacific Ocean (1982 to 1996): evidence of a climate feedback? Geophys. Res. Lett. 24(8), 861-864, doi:10.1029/97GL00784.

Belviso, S., Moulin, C., Bopp, L., Stefels, J., 2004a. Assessment of a global climatology of oceanic dimethylsulfide (DMS) concentrations based on SeaWiFS imagery (1998-2001). Can. J. Fish. Aquat. Sic. 61, 804-816.

Belviso, S., Bopp, L., Moulin, C., Orr, J. C., Anderson, T. R., Aumont, O., Chu, S., Elliott, S., Maltrud, M. E., Simo, R., 2004b. Comparison of global climatological maps of sea surface demethylsulfide. Global Biogeochem. Cycles. 18, GB3013, doi:10.1029/2003GB002193.

Boyer, T. P., Stephens, C., Antonov, J. I., Conkright, M. E., Locarnini, R. A., O'Brien, T. D., Garcia, H. E., 2002. World Ocean Atlas 2001, Volume 2: Salinity. S. Levitus, Ed., NOAA Atlas NESDIS 50, U.S. Government Printing Office, Washington D.C., 165 pp., CD-ROMs.

Chiba, S., Ono, T., Tadokoro, K., Midorikawa, T., Saino, T., 2004. Increased stratification and 
decreased lower trophic level productivity in the Oyashio region of the North Pacific: a 30-year retrospective study. J. Oceanogr. 60, 149-162.

Chu, S., Elliott, S., Maltrud, M. E., 2003. Global eddy permitting simulations of surface ocean nitrogen, iron, sulfur cycling. Chemosphere 50, 223-235.

Conkright, M. E., Garcia, H. E., O'Brien, T. D., Locarnini, R. A., Boyer, T. P., Stephens, C., Antonov, J.I., 2002. World Ocean Atlas 2001, Volume 4: Nutrients. S. Levitus, Ed., NOAA Atlas NESDIS 52, U.S. Government Printing Office, Washington D.C., 392 pp., CD-ROMs.

Emerson, S., Watanabe, Y. W., Ono, T., Mecking, S., 2004. Temporal trends in apparent oxygen utilization in the upper pycnocline of the North Pacific:1980-2000. J. Oceanogr. 60, 139-147.

Global Surface Seawater Dimethylsulfide Database, 2006. NOAA/PMEL DMS Data Server. http://saga.pmel.noaa.gov/dms/

Goes, J., Saino, T., Oaku, H., Ishizaka, J., Wong, C. S., Nojiri, Y., 2000. Basin scale estimates of sea surface nitrate and new production from remotely sensed sea surface temperature and chlorophyll. Geophys. Res. Lett. 27(9), 1263-1266, doi:10.1029/1999GL002353.

Gregg, W. W., Conkright, M. E., 2002. Decadal changes in the global ocean chlorophyll. Geophys. Res. Lett., 29(15), 10.1029/2002GL014689.

Hansen, J., Ruedy, R., Sato, M., Lo, K., 2002. Global warming continues. Science 295, 275, doi:10.1126/science.295.5553.275c.

Honda, M. C., Imai, K., Nojiri, Y., Hoshi, F., Sugawara, T., Kusakabe, M., 2002. The biological pump in the northwestern North Pacific based on fluxes and major components of particulate matter obtained by sediment-trap experiments (1997-2000). Deep-Sea Res. II 49, 5595-5625.

Honda, M., 2003. Biological pump in northwestern North Pacific. J. Oceanogr. 59, 671-684.

Imai, K., Nojiri, Y., Tsurushima, N., Saino, T., 2002. Time series of seasonal variation of primary productivity at station KNOT $\left(44^{\circ} \mathrm{N}, 155^{\circ} \mathrm{E}\right)$ in the sub-arctic western North Pacific. Deep-Sea Res. II 49, 5395-5408.

Institute of Ocean Science, 2006. IOS Line $\mathrm{P}$ Oceanographic Data. http://www-sci.pac.dfo-mpo.gc.ca/osap/data/linep/linepselectdata_e.htm 
Ishida, H., Watanabe, Y. W., Ishizaka, J., Nakano, T., Nagai, N., 2006. Recent trends of chlorophyll-a in the western North Pacific region. submitted to Geophys. Res. Lett.

Japan Meteorological Agency, 2001. Data Report of Oceanographic Observations No. S1, 84-92, CD-ROM.

Karl, D. M., Bidigare, R. R., Letelier, R. M., 2001. Long-term changes in plankton community structure and productivity in the North Pacific Subtropical Gyre: the domain shift hypothesis. Deep-Sea Res. II, 48, 1449-1470.

Kettle, A. J., Andreae, M. O., Amouroux, D., Andreae, T. W., Bates, T. S., Berresheim, H., Bingemer, H., Boniforti, R., Curran, M. A. J., DiTullio, G. R., Helas, G., Jones, G. B., Keller, M. D., Kiene, R. P., Leck, C., Levasseur, M., Malin, G., Maspero, M., Matrai, P., McTaggart, A. R., Mihalopoulos, N., Nguyen, B. C., Novo, A., Putaud, J. P., Rapsomanikis, S., Roberts, G., Schebeske, G., Sharma, S., Simó, R., Staubes, R., Turner, S., Uher, G., 1999. A global database of sea surface dimethylsulfide (DMS) measurements and a prcedure to predict sea surface DMS as a function of latitude, longitude, and month. Global Biogeochem. Cycles 13(2), 399-444, doi:10.1029/1999GB900004.

Levitus, S., Antonov, J. I., Boyer, T. P., Stephens, C., 2000. Warming of the world ocean. Science 287, 2225-2229, doi:10.1126/science.287.5461.2225.

Malin, G., Kirst, G. O., 1997. Algal production of dimethyl sulfide and its atmospheric role. J. Phycol. 33, 889-896.

The NCEP/NCAR Reanalysis Project at the NOAA-CIRES Climate Diagnostics Center (2006): http://www.cdc.noaa.gov/cdc/reanalysis/

Ono, T., Midorikawa, T., Watanabe, Y. W., Tadokoro, K., Saino, T., 2001. Temporal increase of phosphate and apparent oxygen utilization in the subsurface waters of western subarctic Pacific from 1968 and 1998. Geophys. Res. Lett. 28(17), 3285-3288, doi:10.1029/2001GL012948.

Sabine, C. L., Feely, R. A., Watanabe, Y. W., Lamb, M., 2004. Temporal evolution of the North Pacific $\mathrm{CO}_{2}$ uptake rate. J. Oceanogr. 60, 5-15.

Saltzman, E. S., King, D. B., Holmen, K., Leck, C., 1993. Experimental determination of the diffusion coefficient of demethylsulfide in water. J. Geophys. Res. 98(C9), 16481-16486, doi:10.1029/93JC01858. 
Simó, R., Dachs, J., 2002. Global ocean emission of dimethylsulfide predicted from biogeophysical data. Global Biogeochem. Cycles 16(4), 1078, doi:10.1029/2001GB001829.

Stephens, C., Antonov, J. I., Boyer, T. P., Conkright, M. E., Locarnini, R. A., O'Brien, T. D., Garcia, H. E., 2002. World Ocean Atlas 2001, Volume 1: Temperature. S. Levitus, Ed., NOAA Atlas NESDIS 49, U.S. Government Printing Office, Washington D.C., 167 pp., CD-ROMs.

Strickland, J. D. H., Parsons, T. R., 1968. A practical handbook of seawater analysis. Fish. Res. Board of Canada, Bull. 167, 65-75.

Tsurushima, N., Nojiri, Y., Imai, K., Watanabe, S., 2002. Seasonal variations of carbon dioxide system and nutrients in the surface mixed layer at station $\mathrm{KNOT}\left(44^{\circ} \mathrm{N}, 155^{\circ} \mathrm{E}\right)$ in the subarctic western North Pacific. Deep-Sea Res. II 49, 5377-5394.

Wanninkhof, R., McGillis, W. R., 1999. A cubic relationship between air-sea $\mathrm{CO}_{2}$ exchange and wind speed. Geophys. Res. Lett. 26(13), 1889-1892, doi:10.1029/1999GL900363..

Watanabe, S., Yamamoto, H., Tsunogai, S., 1995a. Dimethyl sulfide widely varying in surface water of the eastern North Pacific. Mar. Chem. 51, 253-259.

Watanabe, S., Yamamoto, H., Tsunogai, S., 1995b. Relation between the concentrations of DMS in surface seawater and air in the temperate North Pacific region. J. Atm. Chem. 22, 271-283, doi:10.1007/BF00696638.

Watanabe, Y. W., Ono, T., Shimamoto, A., Sugimoto, T., Wakita, M., Watanabe, S., 2001. Probability of a reduction in the formation rate of the subsurface water in the North Pacific during the 1980s and 1990s. Geophys. Res. Lett. 28(17), 3289-3292, doi:10.1029/2001GL013212.

Watanabe, Y. W., Wakita, M., Maeda, N., Ono, T., Gamo, T., 2003. Synchronous bidecadal periodic changes of oxygen, phosphate and temperature between the Japan Sea deep water and the North Pacific intermediate water. Geophys. Res. Lett. 30(24), 2273, doi:10.1029/2003GL018338.

Watanabe, Y. W., Ishida, H., Nakano, T., Nagai, N., 2005. Spatiotemporal decreases of nutrients and chlorophyll-a in the surface mixed layer of the western North Pacific from 1971 to 2000. J. Oceanogr. 61, 1011-1016.

Watts, S. F., 2000. The mass budgets of carbonyl sulfide, dimethyl sulfide, carbon, disulfide, and 
hydrogen sulfide. Atm. Environ. 34, 761-779.

Wilks, D. S., 1995. Statistical Methods in the Atmospheric Sciences. Academic Press, New York.

Wong, C. S., Waser, N. A. D., Nojiri, Y., Whitney, F. A., Page, J. S., Zeng, J., 2002. Seasonal cycles of nutrients and dissolved inorganic carbon at high and mid latitudes in the North Pacific Ocean during the Skaugran cruises: determination of new production and nutrient uptake ratios. Deep-Sea Res. II 49, 5317-5338.

Wong, C. S., Wong, S. E., Richardson, W. A., Smith, G. E., Arychuk, M. D., Page, J. S., 2005. Temporal and spatial distribution of dimethylsulfide in the subarctic northeast Pacific Ocean: a high-nutrient-low chlorophyll region. Tellus B 57, 317-331.

Yentsch, C. S., Menzel, D. W., 1963. A method for the determination of phytoplankton chlorophyll and phaeophytin by fluorescence. Deep-Sea Res. And Oceanogr. Abst. 10, 221-231. 


\section{Figure Captions}

\section{Figure 1}

Map for the North Pacific indicating the positions of data set of DMS, Chl, SST and SSN used in this study. A bold dotted line, 'EP' indicates the positions of independent DMS dataset set along $140{ }^{\circ} \mathrm{W}$ from $25^{\circ} \mathrm{N}$ to $55^{\circ} \mathrm{N}$ (Bates and Quinn, 1997) which were not used to construct our DMS algorithm (see Subsection 3.1 and Table 1). Bold lines, 'SP' and 'ST' are the subpolar and subtropical time series datasets of hydrographic parameters from 1971 to 2000, respectively (Japan Meteorological Agency, 2001) (see Subsection 3.3 and Table 1).

\section{Figure 2}

Plots of the observed DMS $\left(\mathrm{DMS}_{\mathrm{o}}, \mathrm{nM}\right)$ versus the predicted DMS $\left(\mathrm{DMS}_{\mathrm{p}}, \mathrm{nM}\right)$ over the North Pacific. (a) The plot of $\mathrm{DMS}_{\mathrm{o}}$ and $\mathrm{DMS}_{\mathrm{p}}$ estimated from Eqn. (5) in our study $\left(R^{2}=0.63, R M S E=\right.$ 0.65 (or $\pm 1.9 \mathrm{nM}$ ), $n=504$ ). Solid line represents the 1:1 line between $\mathrm{DMS}_{\mathrm{o}}$ and $\mathrm{DMS}_{\mathrm{p}}$. Both $\mathrm{DMS}_{\mathrm{o}}$ and $\mathrm{DMS}_{\mathrm{p}}$ are shown as natural logarithm values. We also showed the comparison between $\mathrm{DMS}_{\mathrm{o}}$ and $\mathrm{DMS}_{\mathrm{p}}$ in the EP line. Gray triangle, square and circle were the averaged value of sea surface DMS south of $30{ }^{\circ} \mathrm{N}$, that from $30{ }^{\circ} \mathrm{N}$ to $40{ }^{\circ} \mathrm{N}$, and that north of $40{ }^{\circ} \mathrm{N}$, respectively. We here applied an empirical equation of SSN derived from SST and Chl (Goes et al., 2000) to the EP line because the EP line had no data of SSN despite being of the dataset of SST and Chl. The error bars indicate the standard errors of averaged values (SE). (b) Same as Fig. 2a, but calculated from the algorithm of Simó and Dachs (2002) $\left(R^{2}=0.19, R M S E=0.96(\right.$ or $\left.\pm 2.6 \mathrm{nM}), n=504\right)$. The algorithm was based on the ratio of $\mathrm{Chl}$ and the surface mixed layer depth with a difference of $0.125 \sigma_{\theta}$ from the surface density (MLD, m). Thus we here used the same data set of Chl as used to construct our DMS algorithm (see Subsection 3.1, Fig. 1 and Table 1). In these hydrographic data positions, we calculated the monthly MLD based on climatological temperature and salinity data from World Ocean 
Atlas 2001 (Stephens et al., 2002; Boyer et al., 2002). Applying the above Chl and MLD into their algorithm, we obtained the relationship between $\mathrm{DMS}_{\mathrm{o}}$ and $\mathrm{DMS}_{\mathrm{p}}$.

\section{Figure 3}

Climatological distributions of monthly sea surface $\mathrm{DMS}_{\mathrm{p}}(\mathrm{nM})$ in the North Pacific between $25^{\circ} \mathrm{N}$ and $55^{\circ} \mathrm{N}$. These results were reconstructed by using Eqn. (5) with climatological monthly SST and SSN of World Ocean Atlas 2001 (Stephens et al., 2002; Conkright et al., 2002).

\section{Figure 4}

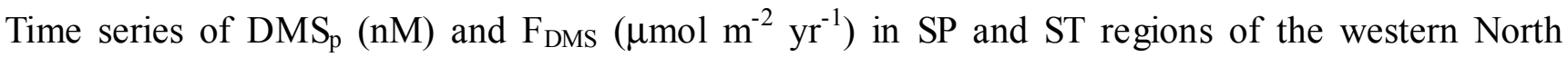
Pacific. $\mathrm{DMS}_{\mathrm{p}}$ was estimated by substituting SST and SSN in the time series datasets for Eqn. (5) (see Subsection 3.3, Fig. 1 and Table 1). We also estimated $F_{D M S}$ by multiplying $D_{M M S}$ with the seasonal wind data at $10 \mathrm{~m}$ height from the NCEP/NCAR reanalysis data (NCEP/NCAR Reanalysis Project, 2006), the gas transfer velocity according to Wanninkhof and McGillis (1999), the Schmidt number calculated according to Saltzman et al. (1993). We showed an averaged value as three-year running mean composites with the standard error (SE) (J-M: black open circles; A-J: green open squares; J-S: red open triangles, O-D: blue open diamonds). Each solid symbol with SE is the averaged value of sea surface DMS observed in the same region in 2004 in SP region and in 1991 in ST region, which was not used to obtain our DMS algorithm. We also showed the linear regression line (solid line) and the non-linear fitting curve (bold dotted curve) which was estimated by the Fourier sine expansion with a $95 \%$ confidence level. (a) $\mathrm{DMS}_{\mathrm{p}}$ in $\mathrm{SP}$ region. (b) $\mathrm{DMS}_{\mathrm{p}}$ in $\mathrm{ST}$ region. (c) $\mathrm{F}_{\mathrm{DMS}}$ in SP region. (d) $F_{D M S}$ in $\mathrm{ST}$ region. The linear increasing trends of $\mathrm{DMS}_{\mathrm{p}}$ and $\mathrm{F}_{\mathrm{DMS}}$ were significantly found as follows: $\mathrm{DMS}_{\mathrm{p}}(\mathrm{J}-\mathrm{M})$ in $\mathrm{SP}=0.01 \mathrm{nM} \mathrm{yr}^{-1}(p<0.01)$; $\mathrm{DMS}_{\mathrm{p}}(\mathrm{J}-\mathrm{S})$ in $\mathrm{SP}=0.03 \mathrm{nM} \mathrm{yr}^{-1}(p<0.05)$; $\mathrm{DMS}_{\mathrm{p}}(\mathrm{O}-\mathrm{D})$ in $\mathrm{SP}=0.04 \mathrm{nM} \mathrm{yr}^{-1}(p<0.01) ; \mathrm{DMS}_{\mathrm{p}}(\mathrm{J}-\mathrm{M})$ in $\mathrm{ST}=0.01 \mathrm{nM} \mathrm{yr}^{-1}(p<0.01) ; \mathrm{DMS}_{\mathrm{p}}$ $(\mathrm{J}-\mathrm{S})$ in $\mathrm{ST}=0.01 \mathrm{nM} \mathrm{yr}^{-1}(p<0.01) . \mathrm{F}_{\mathrm{DMS}}(\mathrm{J}-\mathrm{M})$ in $\mathrm{SP}=1.4 \mu \mathrm{mol} \mathrm{m}^{-2} \mathrm{yr}^{-1}(p<0.05)$; $\mathrm{F}_{\mathrm{DMS}}(\mathrm{A}-\mathrm{J})$ in $\mathrm{SP}=-1.1 \mu \mathrm{mol} \mathrm{m} \mathrm{yr}^{-1}(p<0.05) ; \mathrm{F}_{\mathrm{DMS}}(\mathrm{O}-\mathrm{D})$ in $\mathrm{SP}=18.8 \mu \mathrm{mol} \mathrm{m}^{-2} \mathrm{yr}^{-1}(p<0.01) ; \mathrm{F}_{\mathrm{DMS}}(\mathrm{J}-\mathrm{M})$ in ST 
$=0.9 \mu \mathrm{mol} \mathrm{m}{ }^{-2} \mathrm{yr}^{-1}(p<0.05) ; \mathrm{F}_{\mathrm{DMS}}(\mathrm{J}-\mathrm{S})$ in ST $=2.8 \mu \mathrm{mol} \mathrm{m} \mathrm{yr}^{-1}(p<0.01)$. 
Table 1. A list of cruise information for DMS data set used in this study.

\begin{tabular}{|c|c|c|c|c|}
\hline Cruise name & Sampling date & Sampling area & Numbers of data & References \\
\hline \multicolumn{5}{|c|}{ <DMS, Chl, SSN and SST data set to construct DMS algorithm> } \\
\hline КH1988 & Jun.-Aug. 1988 & $54^{\circ} \mathrm{N}-31^{\circ} \mathrm{N}, 140^{\circ} \mathrm{E}-126^{\circ} \mathrm{W}$ & 71 & Watanabe et al. (1995a, 1995b) \\
\hline KH1997 & Jun.-Sep. 1997 & $55^{\circ} \mathrm{N}-42^{\circ} \mathrm{N}, 148^{\circ} \mathrm{E}-140^{\circ} \mathrm{W}$ & 20 & Aranami et al. (2002) \\
\hline IOS-1996-2001 & May 1996 - Aug. 2001 & $50^{\circ} \mathrm{N}-48^{\circ} \mathrm{N}, 144^{\circ} \mathrm{W}-126^{\circ} \mathrm{W}$ & 255 & Wong et al. (2005), IOS (2006)* \\
\hline 0S1990 & Jul. 1990-Jul.2002 & $54^{\circ} \mathrm{N}-37^{\circ} \mathrm{N}, 160^{\circ} \mathrm{W}-148^{\circ} \mathrm{W}$ & 37 & this study \\
\hline KH1991 & Jan.-Feb. 1991 & $27^{\circ} \mathrm{N}-30^{\circ} \mathrm{N}, 135^{\circ} \mathrm{E}-141^{\circ} \mathrm{W}$ & 67 & this study \\
\hline KT1991 & Jun. 1991 & $34^{\circ} \mathrm{N}-27^{\circ} \mathrm{N}, 133^{\circ} \mathrm{E}-142^{\circ} \mathrm{E}$ & 40 & this study \\
\hline HNF2002-2003 & Jun. 2002-Jun.2003 & $43^{\circ} \mathrm{N}-39^{\circ} \mathrm{N}, 145^{\circ} \mathrm{E}-147^{\circ} \mathrm{E}$ & 14 & this study \\
\hline \multicolumn{5}{|c|}{$\begin{array}{l}\text { <DMS data set to evaluate the validity of DMS algorithm> } \\
\text { (Eastern Pacific: EP) }\end{array}$} \\
\hline $\begin{array}{l}\text { Surveyor } 1993 \\
\text { (Subpolar region: }\end{array}$ & SP) $\quad$ Apr.-May 1993 & $25^{\circ} \mathrm{N}-55^{\circ} \mathrm{N}, 140^{\circ} \mathrm{W}$ & 163 & Bates and Quinn (1997) \\
\hline HNF2004-2005 & Jan. 2004 - Jan. 2005 & $43^{\circ} \mathrm{N}-39^{\circ} \mathrm{N}, 145^{\circ} \mathrm{E}-147^{\circ} \mathrm{E}$ & 39 & this study \\
\hline \multicolumn{5}{|c|}{ (Subtropical region: ST) } \\
\hline КH1991 & Jan.-Feb. 1991 & $27^{\circ} \mathrm{N}-30^{\circ} \mathrm{N}, 137^{\circ} \mathrm{E}-139^{\circ} \mathrm{W}$ & 6 & this study \\
\hline KT1991 & Jul. 1991 & $27^{\circ} \mathrm{N}-30^{\circ} \mathrm{N}, 135^{\circ} \mathrm{E}-141^{\circ} \mathrm{W}$ & 7 & this study \\
\hline \multicolumn{5}{|c|}{$\begin{array}{l}<\text { Hydrographic data set to reconstruct the time series of DMS > } \\
\text { (Subpolar region: SP) }\end{array}$} \\
\hline Kofu & Feb.1971 - Dec. 1998 & $42^{\circ} \mathrm{N}, 144^{\circ} \mathrm{E}-147^{\circ} \mathrm{E}$ & 866 & $\mathrm{JMA}(2001)^{* *}$ \\
\hline \multicolumn{5}{|c|}{ (Subtropical region: ST) } \\
\hline Ryofu & Jan.-Feb. Aug.-Sep. $1971-2000$ & $34^{\circ} \mathrm{N}-25^{\circ} \mathrm{N}, 137^{\circ} \mathrm{E}$ & 1100 & $\mathrm{JMA}(2001)^{* *}$ \\
\hline
\end{tabular}

*: Institute of Ocean Sciences

**: Japan Meteorological Agency 


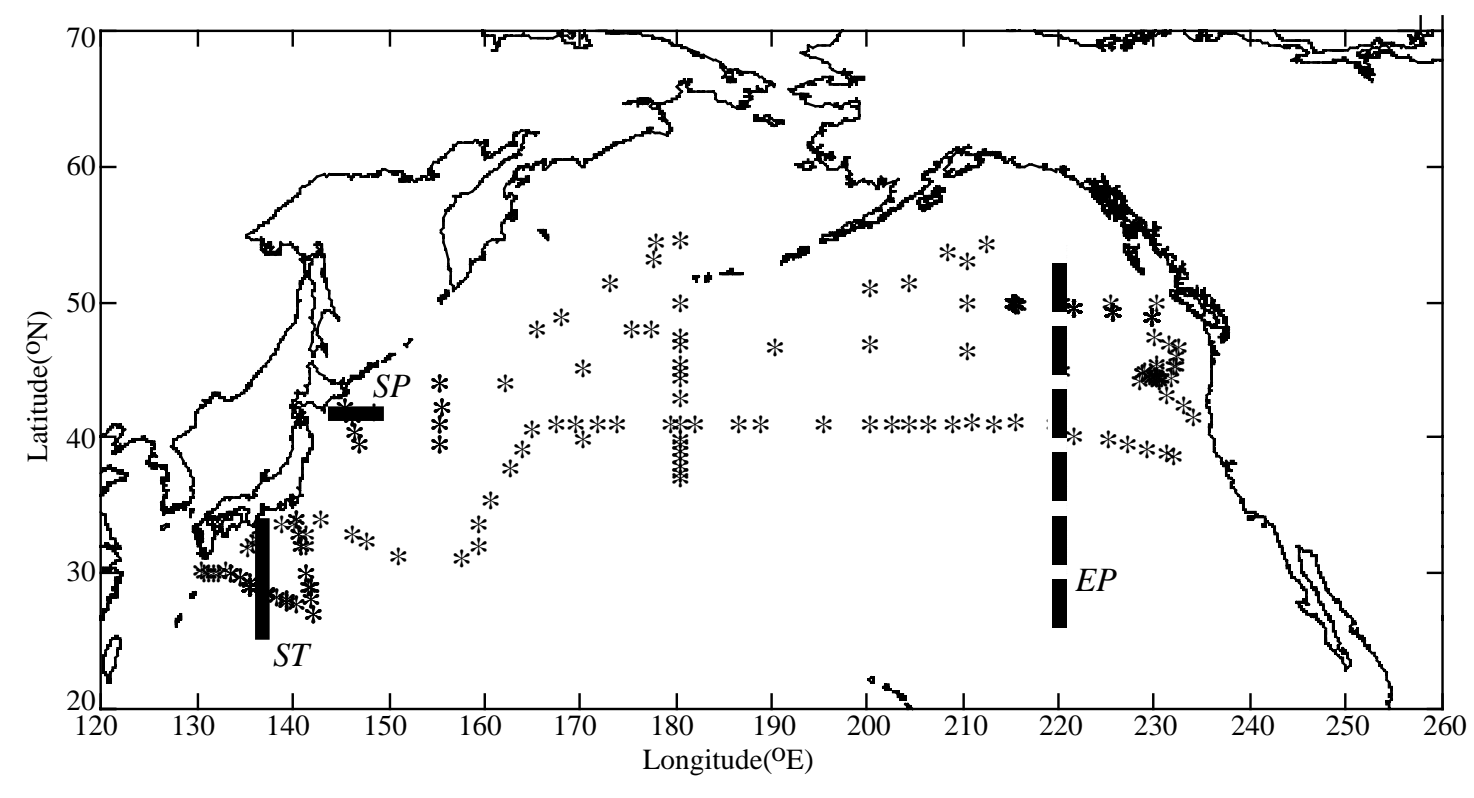

Fig. 1/Watanabe et al. 

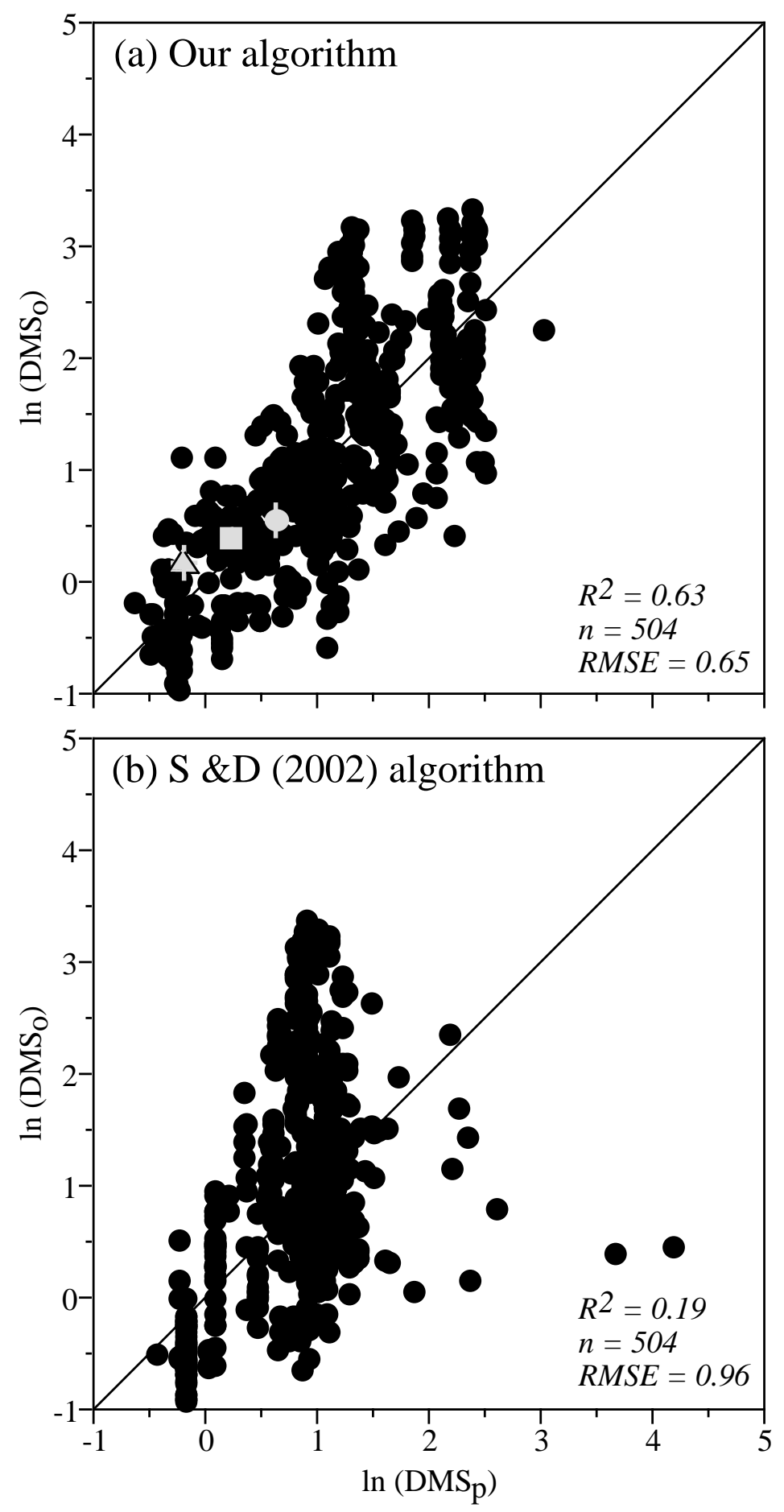

Fig. 2/Watanabe et al. 

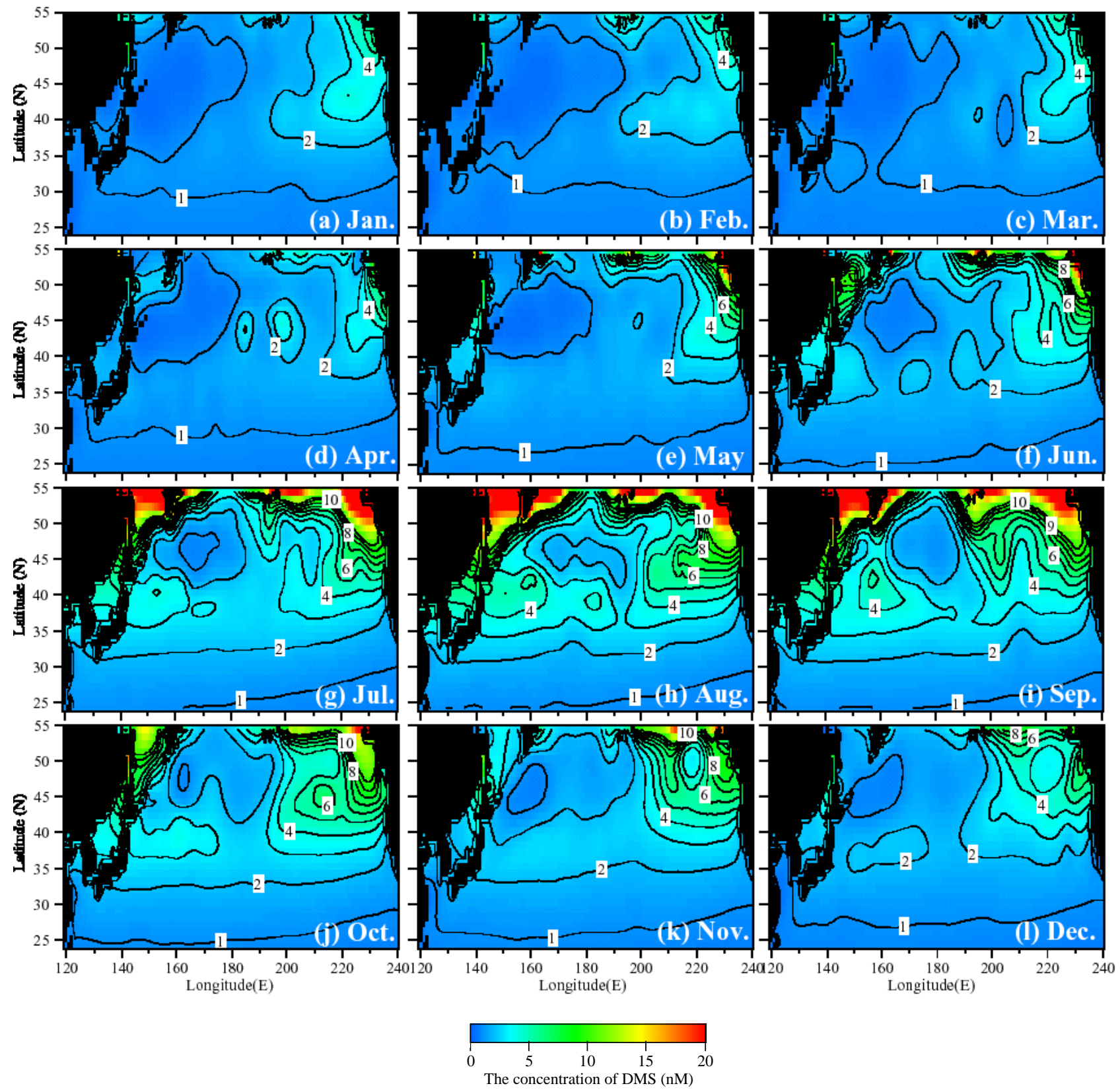

Fig. 3/Watanabe et al. 

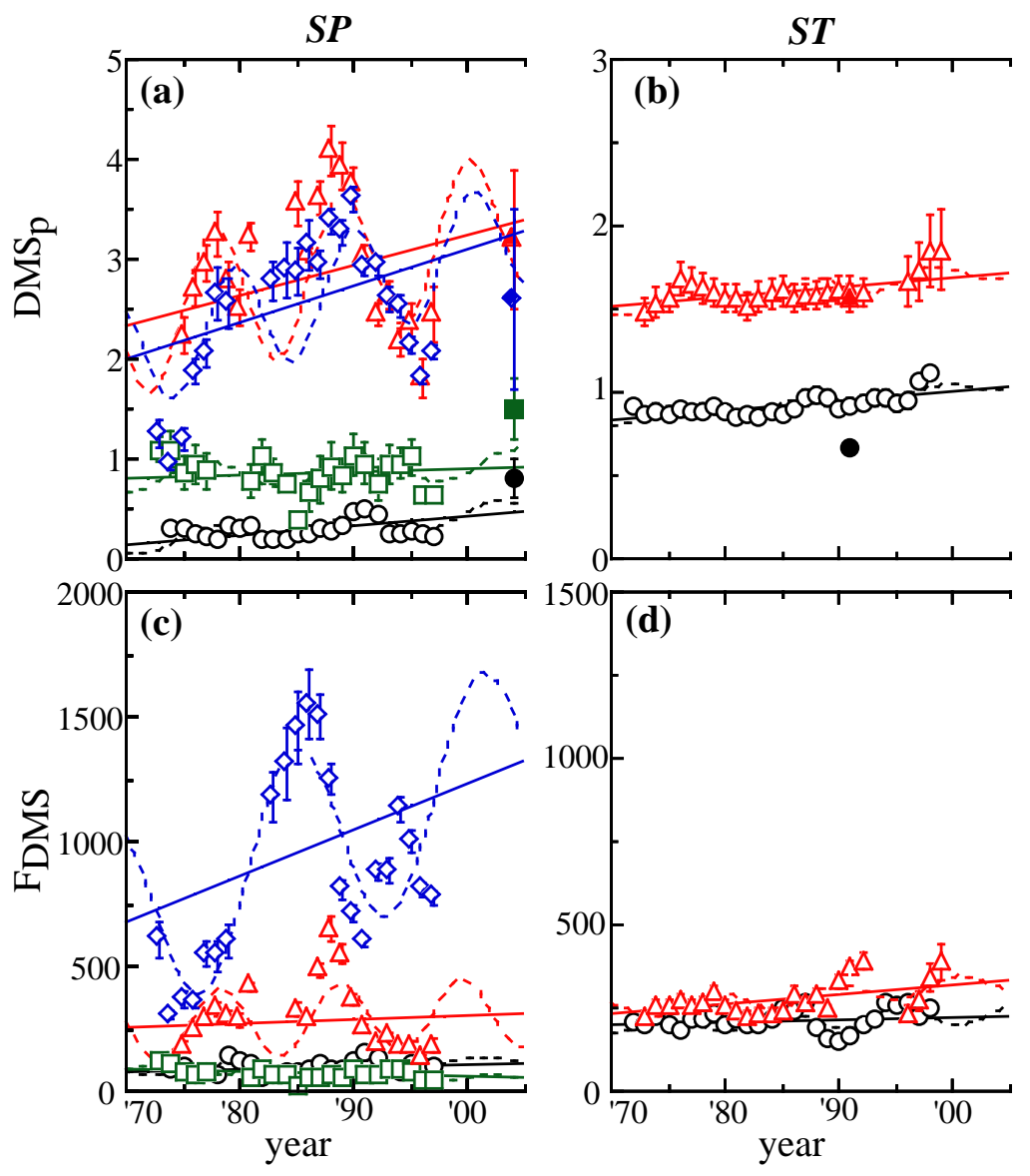

Fig.4/Watanabe et al. 